\title{
Succession of the sea-surface microlayer in the coastal Baltic Sea under natural and experimentally induced low-wind conditions
}

\author{
C. Stolle, K. Nagel, M. Labrenz, and K. Jürgens \\ Leibniz Institute for Baltic Sea Research (IOW), Seestr. 15, 18119 Rostock, Germany \\ Received: 26 March 2010 - Published in Biogeosciences Discuss.: 3 May 2010 \\ Revised: 30 August 2010 - Accepted: 15 September 2010 - Published: 29 September 2010
}

\begin{abstract}
The sea-surface microlayer (SML) is located within the boundary between the atmosphere and hydrosphere. The high spatial and temporal variability of the SML's properties, however, have hindered a clear understanding of interactions between biotic and abiotic parameters at or across the air-water interface. Among the factors changing the physical and chemical environment of the SML, wind speed is an important one. In order to examine the temporal effects of minimized wind influence, SML samples were obtained from the coastal zone of the southern Baltic Sea and from mesocosm experiments in a marina to study naturally and artificially calmed sea surfaces. Organic matter concentrations as well as abundance, ${ }^{3} \mathrm{H}$-thymidine incorporation, and the community composition of bacteria in the SML (bacterioneuston) compared to the underlying bulk water (ULW) were analyzed. In all SML samples, dissolved organic carbon and nitrogen were only slightly enriched and showed low temporal variability, whereas particulate organic carbon and nitrogen were generally greatly enriched and highly variable. This was especially pronounced in a dense surface film (slick) that developed during calm weather conditions as well as in the artificially calmed mesocosms. Overall, bacterioneuston abundance and productivity correlated with changing concentrations of particulate organic matter. Moreover, changes in the community composition in the field study were stronger in the particle-attached than in the nonattached bacterioneuston. This implies that decreasing wind enhances the importance of particle-attached assemblages and finally induces a succession of the bacterial community in the SML. Eventually, under very calm meteorological conditions, there is an uncoupling of the bacterioneuston from the ULW.
\end{abstract}

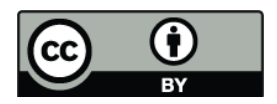

Correspondence to: C. Stolle (christian.stolle@io-warnemuende.de)

\section{Introduction}

The air-water interface constitutes the boundary between the atmosphere and water bodies, which cover about $70 \%$ of the Earth's surface. The sea-surface microlayer (SML) is defined as the uppermost top of the water column and is located at this interface. Although $<1 \mathrm{~mm}$ in thickness, the SML influences exchange processes due to its unique physico-chemical properties compared to those of the underlying water (ULW) (Liss and Duce, 1997). However, the functional importance of bacteria in the SML (bacterioneuston) remains unclear. Despite their potential role in influencing gas exchange (Cunliffe et al., 2008), the contradictory results regarding organic matter enrichment in the SML and the subsequent responses of the bacterioneuston are puzzling.

Repeatedly, the SML has been shown to be enriched in diverse organic and inorganic substances compared to the ULW (Liss and Duce, 1997; Hardy, 1982; Williams et al., 1986). Material in the SML originates from atmospheric deposition, e.g., by dust input or pollination events (Södergren, 1987), or from production in the SML (Reinthaler et al., 2008). The strong correlations with respect to organic and inorganic matter between the SML and the ULW suggest that the ULW is also a major source of these compounds (Baastrup-Spohr and Staehr, 2009; Carlson, 1983; Joux et al., 2006). High concentrations of colloidal material (Bigg et al., 2004) and transparent exopolymer particles (TEP) (Cunliffe et al., 2009b; Wurl and Holmes, 2008) support a model in which the SML is a gelatinous film (Sieburth et al., 1976; Cunliffe and Murrell, 2009). A strong enrichment of particulate as opposed to dissolved matter has often been found in the SML (Hunter, 1997). Nevertheless, elevated concentrations of dissolved substances, such as amino acids and carbohydrates, might support bacterial growth in this layer (Williams et al., 1986; Kuznetsova and Lee, 2002). This is supported by the enhanced enzymatic activities reported in the SML (Münster et al., 1997; Kuznetsova and Lee, 2001),

Published by Copernicus Publications on behalf of the European Geosciences Union. 
suggesting that organic matter in the SML is not only highly concentrated but also utilizable for microbial uptake. However, low bacterial growth efficiencies in the SML indicate that the bacterioneuston only maintains cellular biomass and does not grow strongly (Reinthaler et al., 2008). Other studies, in which increased bacterial respiration rates and decreased bacterioneuston productivity in the SML were reported, confirmed this observation (Obernosterer et al., 2005; Stolle et al., 2009).

The high spatial and temporal variability in the SML might be a reason for this overall inconsistent picture. Variations of SML properties are due to import and export processes (atmospheric deposition, turbulent mixing), temporal successions (seasonality, trophic state), and the accumulation of inhibitory substances (organic pollutants, heavy metals). Moreover, meteorological conditions cause variable patterns in the SML. For instance, UV radiation was suggested to influence diurnal cycles of organic matter transformations and changing bacterial productivity in the SML (Carlucci et al., 1986; Falkowska, 2001). Furthermore, concentrations of particulate organic carbon and bacterial productivity in the SML were shown to be related to wind speed (Obernosterer et al., 2008). However, these factors do not fully explain patterns of bacterioneuston activities (Reinthaler et al., 2008; Santos et al., 2009).

The complexity of processes in the SML clearly leaves large uncertainties about the relation between bacterioneuston communities and the physical and chemical environment of the SML. The aim of this study was to elucidate the dynamics of organic matter accumulation as well as bacterial abundance, activity, and community composition in the SML during minimized wind-induced surface mixing. Wind influences the general physico-chemical properties of the SML in that, with decreasing wind speed, the stability of the SML is expected to increase. Therefore, SML samples were taken in the southern Baltic Sea on four consecutive days under constant low-wind conditions, following the formation and disintegration of a visible surface film (slick). Additionally, mesocosms were installed in a Baltic Sea marina in order to compare naturally influenced and artificially calmed sea surfaces.

\section{Methods}

\subsection{Field study site and sampling}

Samples from the SML were taken in the coastal zone near Warnemuende in the southern Baltic Sea in proximity to position $54^{\circ} 19^{\prime} \mathrm{N}, 12^{\circ} 05^{\prime} \mathrm{E}$ from 6 to 9 May 2008. Sampling was performed between 09:00 and 11:00 LT (local time) from a zodiac against wind direction to avoid contamination of the samples. SML samples were obtained using the glass-plate technique (Harvey and Burzell, 1972) and a framed wiping device which collects layer thicknesses of about $50 \mu \mathrm{m}$ (Stolle et al., 2009) and is in the range of measured SML thicknesses by pH microelectrodes (Zhang et al., 2003). However, there is evidence that glass-plate samples bias measurements of bacterial parameters in the SML due to dilution with bulk water (Cunliffe et al., 2009a) or due to the glass-plates' mode of operation (Hühnerfuss, 1981). Nonetheless, this sampling method was chosen in order to obtain sufficient quantities of the SML. Furthermore, it was previously shown that no bias is introduced into measurements of many bacterial parameters (Agogué et al., 2004; Stolle et al., 2009). Control samples from the ULW were taken from a depth of $1 \mathrm{~m}$ using a 2-1 glass collection tube whose ends were closed by a drop-weight mechanism. Samples were returned to the laboratory and processed for subsequent analysis usually within 1 to $2 \mathrm{~h}$ after sampling. SML measurements were compared to results from the ULW and are expressed as enrichment factors (EF) according to the following definition: $\mathrm{EF}=[x]_{\mathrm{SML}} /[x]_{\mathrm{ULW}}$, where $[x]$ is the concentration of a given parameter (GESAMP, 1995). Wind speed was recorded and the data were provided by the meteorological station in Rostock-Warnemuende, located at the shore in proximity to the study site.

\subsection{Mesocosm experiments}

Mesocosm experiments were performed in a marina within the Warnow River estuary $\left(54^{\circ} 18^{\prime} \mathrm{N}, 12^{\circ} 09^{\prime} \mathrm{E}\right)$ using circular floatation barriers. Each mesocosm had a surface area of $10.5 \mathrm{~m}^{2}$ and was open to the bottom. Three independent experiments were conducted in November and December 2008, with each experiment performed on four consecutive days. While, initially, three mesocosms were employed in each experiment, in each experiment only one mesocosm remained intact during the 4-day period. The other 2 mesocosms in each experiment lost air pressure in the floatation rim and, thus, had to be rejected. Samples were collected daily between 08:00 and 09:00 LT. About 50 ml of the SML was sampled, which was achieved using 7-10 glass-plate samplings. Given the SML's thickness of $27 \mu \mathrm{m}-38 \mu \mathrm{m}$ and a sampling area of the glass-plate of $2000 \mathrm{~cm}^{2}, 13-19 \%$ of the total area inside the mesocosms was sampled. The small sample volume was chosen to avoid sampling of the complete surface inside the mesocosm. The SML outside the mesocosms was sampled in triplicate, with ULW samples taken from a depth of $30 \mathrm{~cm}$ inside and outside the mesocosms. In order to avoid misleading results of chemical and biological parameters in the SML due to initial disturbance upon installation of the mesocosms, SML samples from the first day inside the mesocosms were not included in the analysis.

\subsection{Bacterial abundance and activity}

For the analysis of total bacterial cell numbers, samples were fixed with paraformaldehyde (1\% final concentration)/glutaraldehyde $(0.05 \%$ final concentration) in the dark 
for $1 \mathrm{~h}$ at $5^{\circ} \mathrm{C}$, then frozen in liquid nitrogen and stored at $-80^{\circ} \mathrm{C}$ until analysis by flow cytometry. Heterotrophic bacteria were stained with SYBR Green $(2.5 \mu \mathrm{M}$ final concentration, Molecular Probes) for $30 \mathrm{~min}$ in the dark. Cells were counted at a constant flow rate $\left(35 \mu \mathrm{min}^{-1}\right)$ using a Becton $\&$ Dickinson FACScalibur flow cytometer equipped with a laser emitting at $488 \mathrm{~nm}$. Yellow-green latex beads $(0.5 \mu \mathrm{m}$, Polysciences) were used as an internal standard. Bacteria were detected by their signature in a plot of side scatter (SSC) versus green fluorescence (FL1).

To assess the abundance of highly active bacteria in the mesocosm experiments, $900 \mu \mathrm{l}$ of a sample were incubated with $100 \mu \mathrm{l}$ of a 5-cyano-2,3-ditolyl tetrazolium chloride (CTC, Polysciences) solution (4 mM final concentration) in the dark at the in situ temperature for no longer than $1 \mathrm{~h}$ (Gasol and Arístegui, 2007). CTC uptake was stopped by fixation of the samples with paraformaldehyde (1\% final concentration)/glutaraldehyde ( $0.05 \%$ final concentration) in the dark for $10 \mathrm{~min}$ at $5^{\circ} \mathrm{C}$. The samples were then frozen in liquid nitrogen and stored at $-80^{\circ} \mathrm{C}$. Cells were counted with a flow cytometer as described above, except that the beads for the internal standard were $1 \mu \mathrm{m}$ in size and the cells were detected by their signature in a plot of orange fluorescence (FL2) versus red fluorescence (FL3).

The incorporation of ${ }^{3} \mathrm{H}$-methyl-thymidine $\left({ }^{3} \mathrm{H}-\mathrm{TdR}\right.$, $60.1 \mathrm{Ci} \mathrm{mmol}^{-1}, 10 \mathrm{nM}$ final concentration, Moravek Biochemicals) was measured to determine heterotrophic bacterial productivity in 5-ml water samples from the field study, according to the method of Chin-Leo and Kirchman (1988). Triplicate samples were incubated for $1 \mathrm{~h}$ at the in situ temperature in the dark. Due to sample-volume limitations, triplicates of only $2.5 \mathrm{ml}$ of each sample were incubated in the mesocosm experiments. This, however, had no effect on the observed bacterial productivity compared to 5-ml samples (data not shown). Incorporation was stopped by fixing the cells with formaldehyde $(10 \% \mathrm{v} / \mathrm{w})$ in the dark overnight at $5{ }^{\circ} \mathrm{C}$. A fourth sample, serving as a blank, was fixed for at least $10 \mathrm{~min}$ prior to the addition of ${ }^{3} \mathrm{H}-\mathrm{TdR}$. All samples were filtered on $0.22-\mu \mathrm{m}$ polycarbonate filters (Millipore). Four ml of scintillation cocktail were added to the filters, after which the incorporated substrates were counted in a scintillation counter (Packard).

\subsection{Extraction of nucleic acids and fingerprint analysis}

Water samples from the field study were filtered on 3- $\mu$ m Isopore filters (Millipore), which were presumed to retain the particle-attached fraction. The filtrate (i.e., the non-attached fraction) was then filtered on $0.22-\mu \mathrm{m}$ Isopore filters (Millipore). Water samples from the mesocosm experiments were filtered unfractionated on $0.22-\mu \mathrm{m}$ Isopore filters. All filters were rapidly frozen in liquid nitrogen and stored at $-80^{\circ} \mathrm{C}$. DNA and RNA from frozen filters were extracted using a phenol-chloroform-extraction method, according to Weinbauer et al. (2002). After cell lysis, the samples were divided and a $\mathrm{pH}$-dependent procedure was applied to extract DNA (phenol-chloroform $\mathrm{pH}=7.5-8$ ) or RNA (phenol-chloroform $\mathrm{pH}=4.5-5)$. The resulting extracts were washed and the nucleic-acid content was quantified spectrophotometrically using a NanoDrop ND-1000 Photometer (NanoDrop Technologies).

For the analysis of the presumably active bacterial community, the RNA was reverse transcribed into complementary DNA (cDNA). Co-precipitated DNA was removed using DNAseI (DNA-free kit, Ambion), following the manufacturer's instructions. cDNA was synthesized from 1020 ng RNA in a reverse-transcriptase polymerase chain reaction (RT-PCR) using the universal primer 1492R (5'GGTTACCTTGTTACGACTT-3') (Lane, 1991) and the iScript cDNA synthesis kit (Bio-Rad). The complete removal of DNA was determined with an additional RT-PCR without enzyme. Successful synthesis of the cDNA was confirmed in a following PCR, as described below.

The 16S rRNA (presumably active bacteria) and $16 \mathrm{~S}$ rRNA gene (total bacteria) fingerprints of the bacterial communities were analyzed using single-strandconformation polymorphism (SSCP). DNA extracts as well as cDNA amplicons were PCR-amplified using the primers Com1 (5'CAGCAGCCGCGGTAATAC3') and Com2-Ph (5'CCGTCAATTCCTTTGAGTTT3') (Schwieger and Tebbe, 1998), which amplify Escherichia coli 16S rRNA gene positions 519-926, following the protocol described in Labrenz et al. (2007). The annealing-temperature was $50{ }^{\circ} \mathrm{C}$. Single-stranded DNA was generated and purified and the SSCP analysis carried out as described in Schwieger and Tebbe (1998). Cluster analysis and pairwise comparisons of the band patterns in digitised images were done with GelCompare II (Applied Maths NV) based on their densitometric profiles (Pearson correlation coefficient) after background subtraction, least-square filtering, and optimization which were used for background removal, smoothing of the profiles and to optimize the settings for the analyses, respectively, according to the manufacturers' instructions. The pairwise comparison of the bacterioneuston and bacterioplankton community is expressed as the percentage dissimilarity.

\subsection{Analysis of organic carbon and nitrogen}

Ten-ml water samples from the mesocosm experiments were sealed in $\mathrm{HCl}$-precleaned and precombusted $\left(450^{\circ} \mathrm{C}, 6 \mathrm{~h}\right)$ glass ampoules using a portable propane torch. The sealed ampoules were quickly frozen without the addition of preservatives and then stored at $-20^{\circ} \mathrm{C}$ until analysis in the laboratory. Total organic carbon (TOC) and total nitrogen $(\mathrm{TN})$ were quantified using a high-temperature combustion method, carried out in the presence of a Pt-catalyst on a Shimadzu TOC-V analyzer supplemented with a Shimadzu TNM-1 nitrogen detector and a Shimadzu ASI-V autosampler (Shimadzu Europe Ltd.). This system allows 
simultaneous determination of TOC and TN in the same sample. The temperature of the catalyst was kept at $680^{\circ} \mathrm{C}$ and carbon-free air produced by a Whatman gas generator was used as carrier gas (flow rate: $150 \mathrm{ml} \mathrm{min}{ }^{-1}$ ). Acetanilide was used for a 4-point calibration. Prior to analysis, the samples were acidified with $2 \mathrm{~N} \mathrm{HCl}$ (suprapure grade) to a final $\mathrm{pH}<2$. Calculations of TOC and TN concentrations were based on four injections of the sample (injection volume: $75 \mu \mathrm{l})$. All samples were run in duplicate. The reliability of each analytical run was checked using external reference material in a seawater matrix for TOC and TN and using reference material for blank measurement. The reference material was obtained from Dennis Hansell's CRM program (Dennis Hansell, University of Miami).

For the analysis of particulate organic carbon (POC) and nitrogen (PN), 50-500 $\mathrm{ml}$ (field study) and 95-250 $\mathrm{ml}$ (subset of samples from the mesocosm experiments) of sample were filtered through Whatman GF/F glass-fiber filters (approximately $0.7 \mu \mathrm{m}$ pore size, precombusted at $450^{\circ} \mathrm{C}$ for $6 \mathrm{~h})$. After filtration, the filters were transferred into $10-\mathrm{ml}$ rolled-rim vials and stored at $-20^{\circ} \mathrm{C}$. Prior to analysis, particulate inorganic carbon (PIC) was dispersed by acidifying the thawed filter with $100 \mu \mathrm{l}$ of $2 \mathrm{~N} \mathrm{HCl}$. After an incubation of approximately $30 \mathrm{~min}$, the filters were dried at $60^{\circ} \mathrm{C}$ for $4 \mathrm{~h}$. For final measurements, the dry filters were transferred into small tin boats and analyzed in an Elementar vario MICRO cube elemental analyzer (Elementar Analysensysteme $\mathrm{GmbH}$, Germany) using the standard protocol recommended by the manufacturer. Acetanilide was used for calibration. The filtrate, i.e. dissolved organic carbon (DOC) and dissolved nitrogen (DN) was analyzed as described for TOC and $\mathrm{TN}$ (see above). Measurements uncertainties for DOC, DN, POC and PN were $<5 \mu \mathrm{moll}^{-1},<3 \mu \mathrm{moll}^{-1},<1.3 \mu \mathrm{M}$ and $<0.5 \mu \mathrm{M}$, respectively.

\subsection{Statistical analysis}

Statistical analyses of the results from the mesocosm experiments were based on non-parametric tests, as normal distribution was either rejected using the Kolmogorov-Smirnoff test or the sample numbers were too small for proper testing. To examine the equality of the means between the SML and the ULW samples as well as among the SML samples, the Wilcoxon test and the Friedman test, respectively, were chosen. A significance level of $p<0.05$ indicated that the means of the samples were significantly different. Spearman's rank correlation was applied to test the association between parameters in the SML and the ULW. Again, $p<0.05$ indicated significant correlation.
Table 1. Wind speed in May 2008 during sea-surface microlayer sampling as well as mean values for a $6-\mathrm{h}$ period prior to sampling. Samples were taken in the southern Baltic Sea offshore Warnemuende in proximity to position $54^{\circ} 19^{\prime} \mathrm{N} ; 12^{\circ} 05^{\prime} \mathrm{E}$.

\begin{tabular}{lcc}
\hline Date & Wind speed $\left(\mathrm{m} \mathrm{s}^{-1}\right)$ & $\begin{array}{c}\text { Wind speed }\left(\mathrm{m} \mathrm{s}^{-1}\right) \\
6 \mathrm{~h} \text { mean }\end{array}$ \\
\hline 6 May 2008 & 3.80 & 2.30 \\
7 May 2008* & 1.90 & 1.08 \\
8 May 2008 & 1.50 & 2.12 \\
9 May 2008 & 2.60 & 2.53 \\
\hline
\end{tabular}

*visible slick formation

\section{Results}

\subsection{Field study}

The SML in the southern Baltic Sea was sampled on four consecutive days, from 6 to 9 May 2008 (days 1-4), using the glass-plate technique. SML thickness, determined by the sample volume per area of the sampling device, was only measured on day 2 and was $46 \mu \mathrm{m}$. This was in the range of previously reported values (Stolle et al., 2009). All sampling days were characterized by a wind speed $<3.8 \mathrm{~m} \mathrm{~s}^{-1}$ during sampling as well as within the $6 \mathrm{~h}$ prior to sampling (Table 1 ). On day 2 , the sea surface was very calm, resulting in the formation of a visible surface film (slick) with considerably altered visible reflectance characteristics. The following day, this slick began to disintegrate and it disappeared completely by day 4 , in parallel with the increasing wind speed of up to $2.6 \mathrm{~m} \mathrm{~s}^{-1}$.

\subsubsection{Organic carbon and nitrogen}

The pool of organic carbon and nitrogen in the SML underwent major changes throughout the sampling period, with high-level accumulations during slick formation (day 2, Fig. 1a). The concentrations of POC and PN in the SML increased from $25.2 \mu \mathrm{mol} \mathrm{POCl} 1^{-1}$ and $5.9 \mu \mathrm{mol} \mathrm{PN1}^{-1}$ on day 1 to $791.3 \mathrm{POC}_{\mu \mathrm{mol}} \mathrm{l}^{-1}$ and $76.4 \mathrm{PN} \mu \mathrm{moll}^{-1}$ on day 2 . In the ULW, POC ranged between 20.8 and $35.1 \mu \mathrm{mol} \mathrm{l}^{-1}$ and PN between 2.8 and $5.5 \mu \mathrm{mol} \mathrm{1}^{-1}$. This resulted in high enrichment factors for POC (26.8) and PN (19.5) on day 2. Disintegration of the slick (days 3 and 4) was accompanied by a subsequent decrease in the absolute and relative values of POC and PN in the SML, although there was still an overall enrichment compared to the ULW (Fig. 1a). In the slick, POC and PN concentrations contributed $70 \%$ and $79 \%$ to TOC and TN, respectively, compared to only $11 \%$ POC and $14 \%$ PN during pre-slick conditions and 6-9\% POC and $14-18 \%$ PN in the ULW on all sampling days.

In the ULW, DOC and DN were highest on day 1 $\left(355.7 \mu \mathrm{mol}^{-1}\right.$ and $34.4 \mu \mathrm{mol}^{-1}$, respectively), but over 

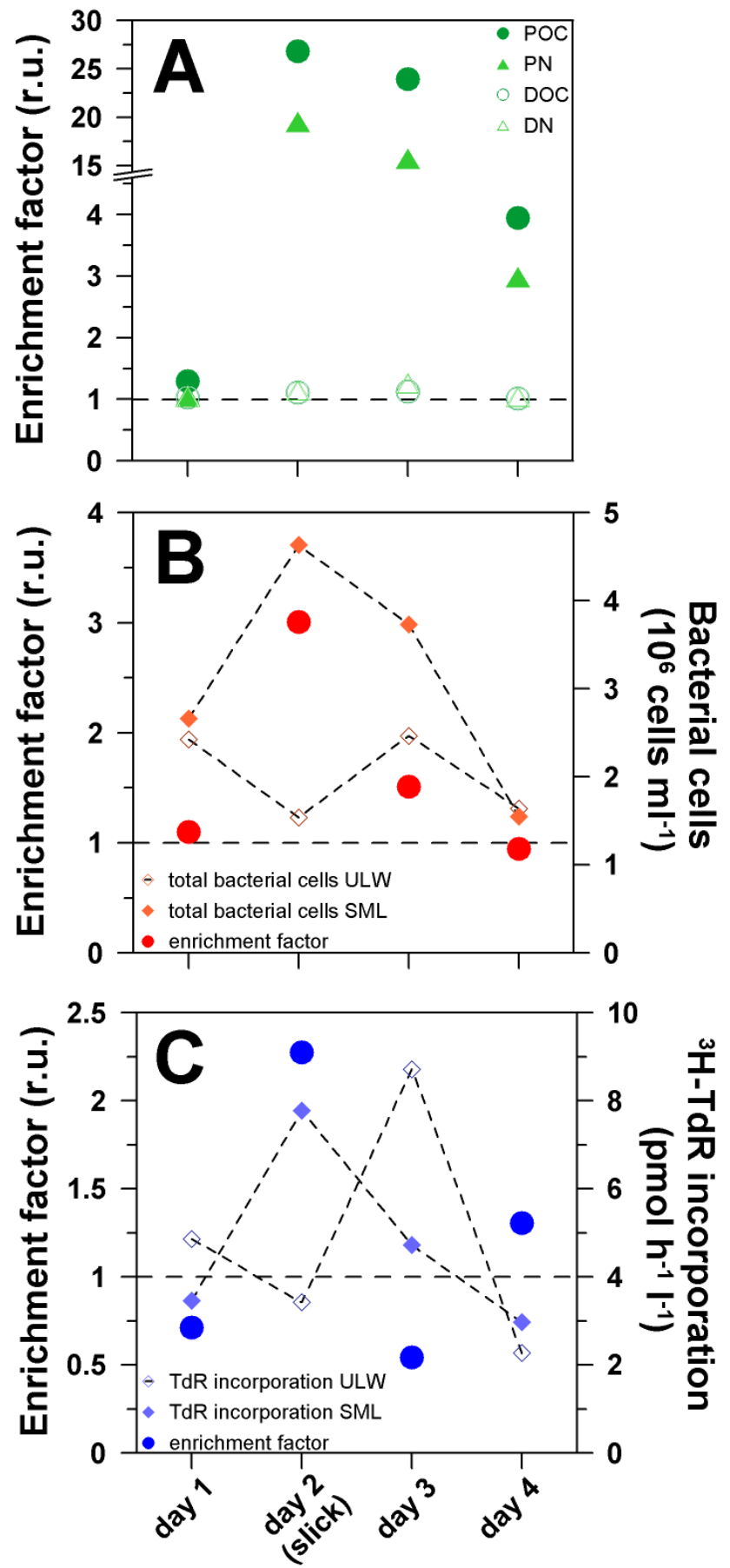

Fig. 1. Changes of organic carbon and nitrogen (A), bacterial abundance (B), and bacterial incorporation of ${ }^{3} \mathrm{H}$-thymidine (C) throughout the formation and disintegration of a visible surface film (slick) in the southern Baltic Sea. Values are given as enrichment factors (EF), i.e., relative ratios between the sea-surface microlayer and the underlying water. Dashed lines indicate $\mathrm{EF}=1$, in which case the values in the samples were equal. Additionally, absolute values for the bacterial parameters are indicated. the remaining sampling period they were relatively stable (310.6-314.5 $\mathrm{moll}^{-1}$ and $15.7-17.4 \mu \mathrm{mol}^{-1}$, respectively). DOC and DN showed only slight accumulations in the SML (Fig. 1a), with the highest enrichment factors measured on day 3 for both DOC (1.1) and DN (1.3).

\subsubsection{Bacterial abundance, activity, and community composition}

Enrichment factors for total bacterial cell numbers (3.0) and ${ }^{3} \mathrm{H}$-TdR incorporation (2.3) were highest in the slick (Fig. 1b and c). On day $2,4.6 \times 10^{6}$ bacterial cells $\mathrm{ml}^{-1}$ were measured in the SML, which was nearly twice as high as on day 1; however, with dissolution of the slick on days 3 and 4 the number of cells decreased even below the value of day 1 (Fig. 1b). A similar pattern was observed for bacterioneuston productivity, which peaked in the slick and subsequently decreased over the following days to the initial value of day 1 (Fig. 1c). Interestingly, total bacterial cell numbers and ${ }^{3} \mathrm{H}$ TdR incorporation in the ULW decreased slightly on day 2 (slick) and increased on day 3. Therefore, the enrichment factor for ${ }^{3} \mathrm{H}-\mathrm{TdR}$ incorporation on day 3 was smaller $(0.5)$ than that on day 2 (2.3) and day 4 (1.3).

A comparison of bacterioplankton and bacterioneuston community composition, using 16S rRNA (presumably active bacteria) and 16S rRNA gene (total bacteria) fingerprints, revealed strong changes throughout the sampling period. The differences in community composition of nonattached bacteria between the SML and ULW were initially $<10.1 \%$ in both the $16 \mathrm{~S}$ rRNA gene and the $16 \mathrm{~S}$ rRNA fingerprints (Fig. 2a). However, in the slick, this dissimilarity increased to $33.7 \%$ (16S rRNA gene) and 53.3\% (16S rRNA) due to major changes within the bacterioneuston community composition. This was illustrated in a cluster analysis, in which all ULW samples and the remaining SML samples grouped clearly together (Fig. 2b).

An overall similar pattern was observed in a comparison of the $16 \mathrm{~S}$ rRNA and rRNA gene fingerprints of the particle-attached bacterial communities (Fig. 2a), but there were also a few differences: (1) the dissimilarities between the bacterioneuston and bacterioplankton community in the $16 \mathrm{~S}$ rRNA gene fingerprints were higher than in the corresponding $16 \mathrm{~S}$ rRNA fingerprints, except on day 1 ; (2) the dissimilarities between the bacterioneuston and bacterioplankton community were generally higher in the particle-attached than in the non-attached fraction; and (3) during slick disintegration, the dissimilarities in the particle-attached fraction did not decrease as much as they did in the non-attached fraction. Nonetheless, cluster analysis of the particle-attached 16S rRNA fingerprints showed that the bacterioneuston community in the slick was least similar to all other samples (Fig. 2c).

In summary, slick formation in the southern Baltic Sea enhanced bacterial abundance and productivity in the SML and induced strong changes in bacterioneuston community 

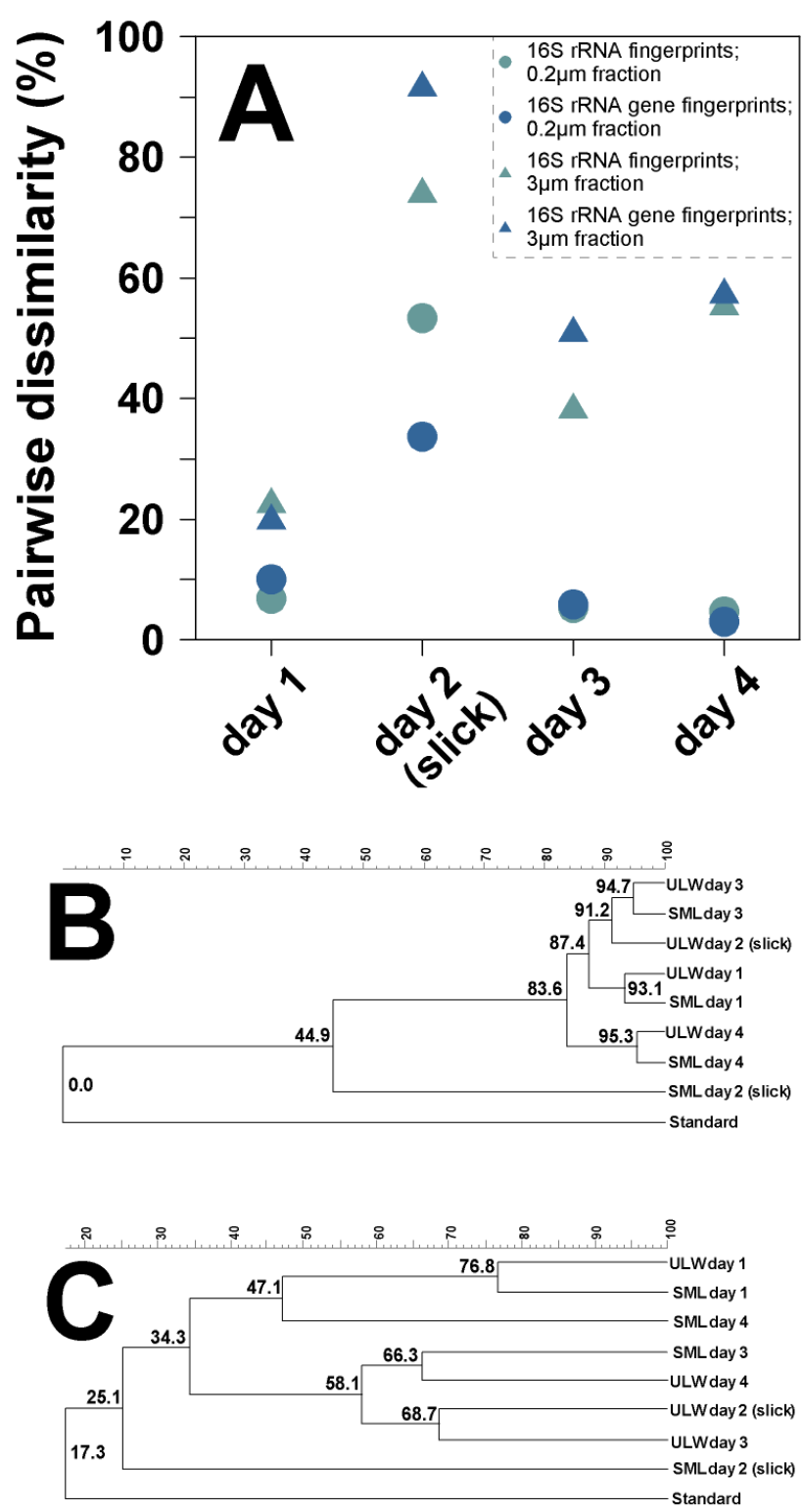

Fig. 2. Analysis of the bacterial community composition in the Baltic Sea field study based on 16S rRNA and 16S rRNA gene fingerprints. (A) Pairwise dissimilarity between bacterioneuston (SML) and bacterioplankton (ULW) community profiles for the particle-attached and non-attached fraction. (B, C) Cluster analyses of 16S rRNA fingerprints of the non-attached (B) and of the particle-attached $(\mathbf{C})$ fractions show strong changes in the bacterioneuston community during slick formation.

composition. Moreover, slick formation was characterized by a strong accumulation of particulate matter.

\subsection{Mesocosm experiments}

Temporal changes of the SML under artificially calmed vs. natural, wind-affected sea surfaces were studied in mesocosm experiments. The study site was heavily influenced by the opposing inflow of water from brackish (Baltic Sea) and limnic (Warnow River) sources. Nevertheless, measurements of several biotic and abiotic parameters revealed highly comparable conditions in all ULW samples inside and outside the mesocosms (Supplement Fig. 1).

\subsubsection{Dynamics of organic carbon and nitrogen}

Absolute concentrations of TOC and TN in all samples as well as DOC, DN, POC and PN in a subset of samples (see below) were in the range of previously reported values from the southern Baltic Sea (Nausch et al., 2009; Supplement Table 1). Inside and outside the mesocosms, TOC and TN in the SML showed similar characteristics. The concentrations of both were highly variable but overall enriched compared to the ULW (Wilcoxon test; $p \leq 0.008, n \geq 9$; Table 2). The enrichment factors for TN were higher than those for TOC (Wilcoxon test; $p \leq 0.008, n \geq 9$ ), but the two sets of values correlated significantly with each other (Spearman $r_{\mathrm{s}} \geq 0.767, p \leq 0.016, n \geq 9$ ). Absolute concentrations of these parameters in the SML did not correlate with those of the ULW inside the mesocosms and did so only weakly outside the mesocosms (Table 2).

Outside the mesocosms, POC and DOC as well as PN and DN were measured on the first and last day of each experiment. Enrichment factors for POC and PN ranged between 2.2 and 16.4 and about doubled throughout the first and third experiment. Yet, on the last day of each experiment, enrichments outside the mesocosms were not as pronounced as those inside the mesocosms (Table 3). Here, POC, DOC, $\mathrm{PN}$, and DN were analyzed only on the last day of each experiment due to sample-volume limitations. Enrichment factors for POC inside the mesocosms ranged between 9.5 and 22.6 (Table 3). In the SML inside the mesocosms, 27-60\% of TOC consisted of POC (Table 3), compared to $4-8 \%$ in the ULW (data not shown) and $14-47 \%$ in the SML outside the mesocosms (Table 3). A comparable pattern was found for the enrichment of PN (Table 3). DOC and DN were only slightly but similarly enriched in all SML samples (1.1-1.3 and 1.0-1.7, respectively).

\subsubsection{Bacterial parameters}

Bacterial abundance and productivity in the SML were, in general, highly variable (Fig. 3c-e). Overall, CTC-positive cells were enriched in all SML samples (Wilcoxon test; $p \leq 0.008, n \geq 9$; Table 2, Fig. 3d), but the absolute values of the SML did not correlate with those of the ULW (Table 2). Inside and outside the mesocosms, absolute total bacterial cell numbers were enriched in the SML (Wilcoxon test; $p \leq 0.011, n \geq 9$, Table 2, Fig. 3c). ${ }^{3} \mathrm{H}-\mathrm{TdR}$ incorporation in the SML outside the mesocosms was slightly decreased compared to the ULW (Wilcoxon test; $p=0.010, n=36$; Table 2, Fig. 3e) whereas in the SML inside the mesocosms it was highly variable and not significantly different from ${ }^{3} \mathrm{H}-\mathrm{TdR}$ 

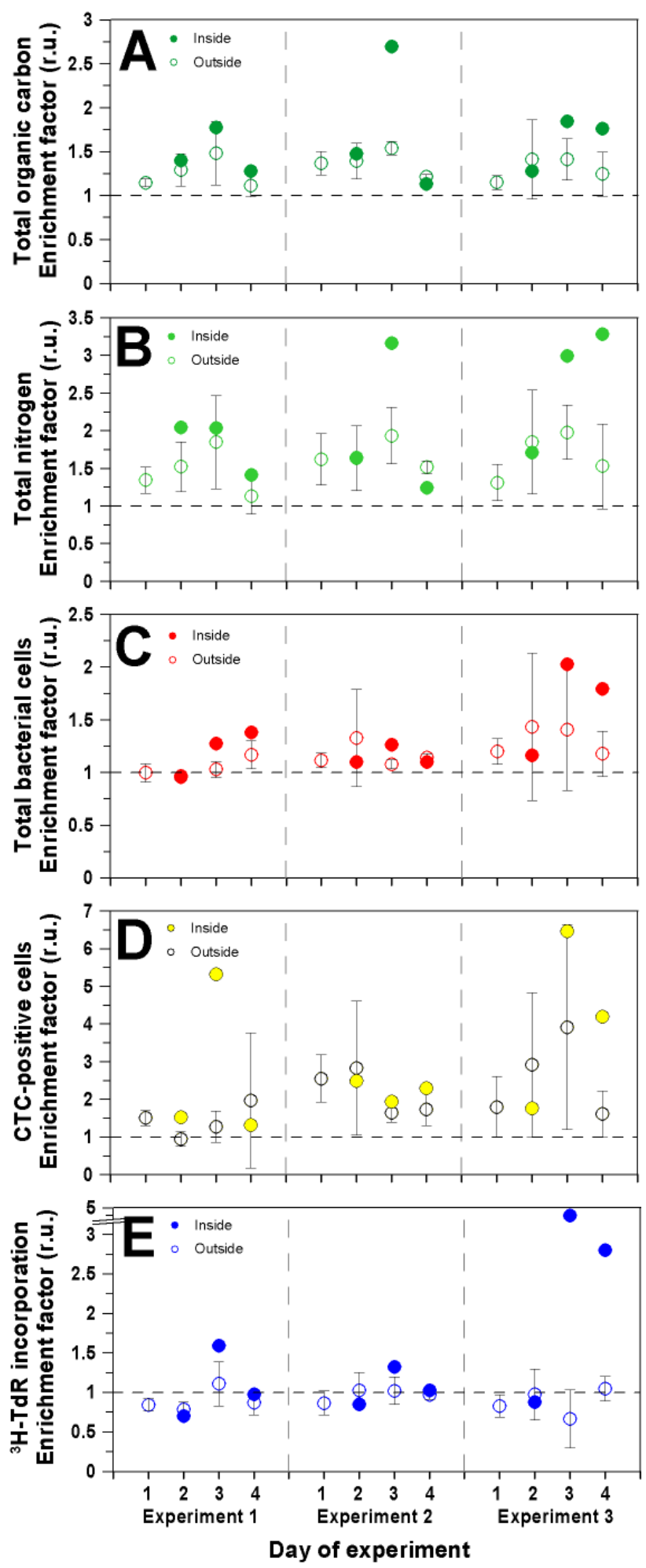

Fig. 3. Enrichment factors of total organic carbon (A), total nitrogen (B), abundance of total bacterial cells (C), and CTC-positive cells (D) as well as the incorporation of ${ }^{3} \mathrm{H}$-thymidine (E) are given for the sea-surface microlayer inside (coloured circles) and outside (white circles) the mesocosms. Results of three experiments are shown. Error bars indicate standard deviation of three independent samples.
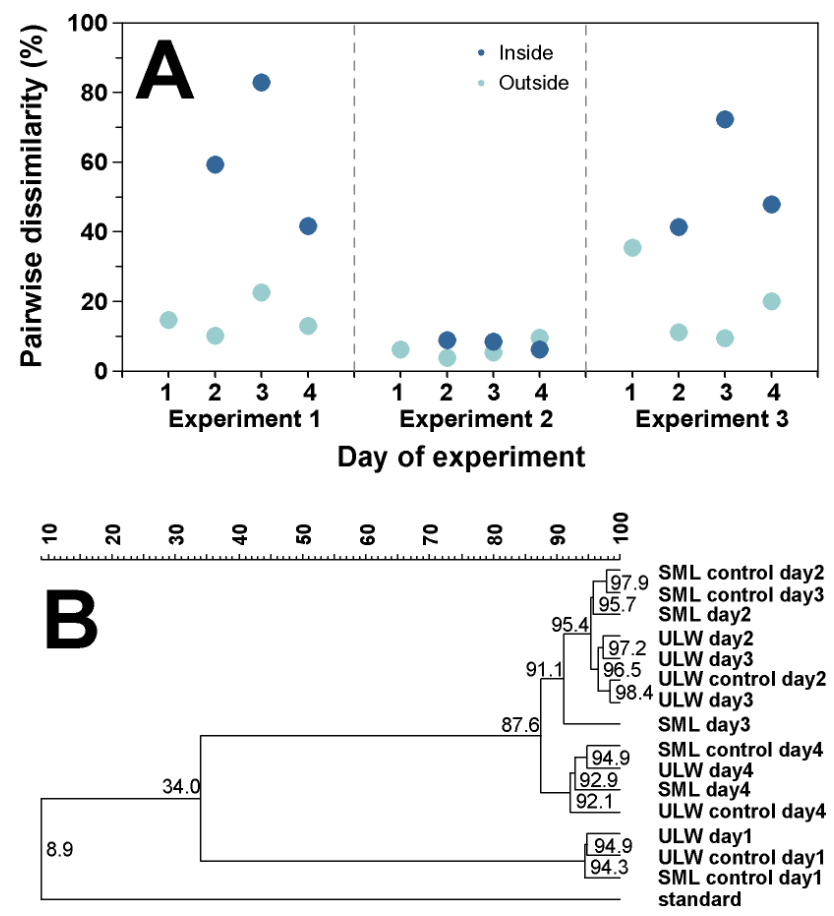

Fig. 4. (A) Pairwise comparison of the total bacterioneuston community inside (coloured circles) and outside (white circles) the mesocosms with respect to bacterioplankton community based on 16S rRNA fingerprints. (B) Cluster analysis of all communities as revealed by their single-strand conformation polymorphism (SSCP) band patterns over the course of four days during the second experiment. The day of the experiment as well as the origin of the samples are indicated $(\mathrm{SML}=$ sea-surface microlayer, $\mathrm{ULW}=$ underlying water, control $=$ outside mesocosms).

incorporation in the ULW (Wilcoxon test; $p=0.347, n=9$; Table 2, Fig. 3e). Bacterial cell numbers and ${ }^{3} \mathrm{H}-\mathrm{TdR}$ incorporation in the SML correlated with the corresponding values in the ULW outside but not inside the mesocosms (Table 2). To test whether enrichments inside the mesocosms were different from those outside the mesocosms, enrichment factors among all samples were compared. The results implied that the enrichment of CTC-positive cells and ${ }^{3} \mathrm{H}-\mathrm{TdR}$ incorporation were not statistically different inside vs. outside the mesocosms (Table 2).

The total bacterial community composition was analyzed by $16 \mathrm{~S}$ rRNA fingerprinting. During the first and third experiments, the differences between the bacterioneuston and bacterioplankton communities were found to be highly dynamic (Fig. 4a). Outside the mesocosms, the dissimilarity in community composition between SML (bacterioneuston) and ULW (bacterioplankton) during experiments 1 and 3 was always lower than inside the mesocosms (Fig. 4a). In both experiments, the highest dissimilarities between SML and ULW inside the mesocosms occurred on the third day $(82.9 \%$ and $72.3 \%$ in experiment 1 and 3, respectively). By contrast, throughout the second experiment, the dissimilarities 
Table 2. Comparison between samples from the sea-surface microlayer (SML) inside and outside the mesocosms with respect to the underlying water (ULW). For each parameter, potential differences in absolute values between the SML and ULW (Wilcoxon test) were tested, as were potential correlations between these values (Spearman-rho correlation coefficient). Moreover, the enrichment factors among all SML-samples inside and outside the mesocosms were examined for significant differences (Friedman test).

\begin{tabular}{|c|c|c|c|c|c|}
\hline & \multicolumn{2}{|c|}{$\begin{array}{l}\text { Inside mesocosms } \\
\text { SML vs. ULW }\end{array}$} & \multicolumn{2}{|c|}{$\begin{array}{c}\text { Outside mesocosms } \\
\text { SML vs. ULW }\end{array}$} & \multirow{2}{*}{$\begin{array}{l}\text { Enrichment factors } \\
\text { all SMLs } \\
\text { Friedman }\end{array}$} \\
\hline & Wilcoxon & Spearman $\left(r_{\mathrm{s}}\right)$ & Wilcoxon & Spearman $\left(r_{\mathrm{s}}\right)$ & \\
\hline $\begin{array}{l}\text { Total organic } \\
\text { carbon }\end{array}$ & $\begin{array}{l}p=0.008 \\
n=8\end{array}$ & $\begin{array}{l}0.262 \\
\text { n.s.; } n=8\end{array}$ & $\begin{array}{l}p<0.001 \\
n=35\end{array}$ & $\begin{array}{l}0.076 \\
\text { n.s.; } n=35\end{array}$ & $\begin{array}{l}p=0.224 \\
n=8\end{array}$ \\
\hline Total nitrogen & $\begin{array}{l}p=0.008 \\
n=8\end{array}$ & $\begin{array}{l}-0.310 \\
\text { n.s.; } n=8\end{array}$ & $\begin{array}{l}p<0.001 \\
n=35\end{array}$ & $\begin{array}{l}0.384 \\
* ; n=35\end{array}$ & $\begin{array}{l}p=0.134 \\
n=8\end{array}$ \\
\hline $\begin{array}{l}\text { Total } \\
\text { bacterial cells }\end{array}$ & $\begin{array}{l}p=0.011 \\
n=9\end{array}$ & $\begin{array}{l}0.583 \\
\text { n.s.; } n=9\end{array}$ & $\begin{array}{l}p<0.001 \\
n=35\end{array}$ & $\begin{array}{l}0.685 \\
* * * ; n=35\end{array}$ & $\begin{array}{l}p=0.215 \\
n=9\end{array}$ \\
\hline $\begin{array}{l}\text { CTC-positive } \\
\text { cells }\end{array}$ & $\begin{array}{l}p=0.008 \\
n=9\end{array}$ & $\begin{array}{l}0.333 \\
\text { n.s.; } n=9\end{array}$ & $\begin{array}{l}p<0.001 \\
n=36\end{array}$ & $\begin{array}{l}0.197 \\
\text { n.s.; } n=36\end{array}$ & $\begin{array}{l}p=0.008^{1} \\
n=9\end{array}$ \\
\hline $\begin{array}{l}{ }^{3} \mathrm{H}-\mathrm{TdR} \\
\text { incorporation }\end{array}$ & $\begin{array}{l}p=0.374 \\
n=9\end{array}$ & $\begin{array}{l}0.217 \\
\text { n.s.; } n=9\end{array}$ & $\begin{array}{l}p=0.010 \\
n=36\end{array}$ & $\begin{array}{l}0.947 \\
* * * ; n=36\end{array}$ & $\begin{array}{l}p=0.040^{1} \\
n=9\end{array}$ \\
\hline
\end{tabular}

Bold values indicate significantly different (Wilcoxon test) or significantly correlated (Spearman-rho) comparison. $r_{\mathrm{S}}=$ Spearman- $\rho$ correlation coefficient; level of significance is indicated as follows: $* * *=p<0.001$; $* *=p<0.01 ; *=p<0.05$; n.s. $=$ not significant; ${ }^{1}$ Bonferroni-correction showed that each single comparison within the Friedman test was not significant (data not shown).

Table 3. Enrichment factors (EF) of particulate organic carbon (POC) and particulate nitrogen (PN) inside and outside the mesocosms. Outside the mesocosms, samples were taken on the first and the last day of each experiment; inside the mesocosms, samples were only taken on the last day of each experiment. Values in parentheses indicate contribution of the particulate matter to the total organic matter pool (\%).

\begin{tabular}{|c|c|c|c|c|c|}
\hline \multirow[b]{2}{*}{ Experiment } & \multirow[b]{2}{*}{$\begin{array}{c}\text { Day of } \\
\text { experiment }\end{array}$} & \multicolumn{2}{|c|}{$\mathrm{EF}(\mathrm{POC})$} & \multicolumn{2}{|c|}{$\mathrm{EF}(\mathrm{PN})$} \\
\hline & & $\begin{array}{c}\text { Inside } \\
\text { mesocosms }\end{array}$ & $\begin{array}{c}\text { Outside } \\
\text { mesocosms* }\end{array}$ & $\begin{array}{c}\text { Inside } \\
\text { mesocosms }\end{array}$ & $\begin{array}{c}\text { Outside } \\
\text { mesocosms }\end{array}$ \\
\hline \multirow[t]{2}{*}{1} & 1 & n.d. & $\begin{array}{c}2.16 \pm 0.96 \\
(14.1)\end{array}$ & n.d. & $\begin{array}{c}2.17 \pm 1.02 \\
\quad(13.2)\end{array}$ \\
\hline & 4 & $\begin{array}{l}12.76 \\
(48.8)\end{array}$ & $\begin{array}{c}6.13 \pm 3.19 \\
(30.0)\end{array}$ & $\begin{array}{c}9.62 \\
(43.0)\end{array}$ & $\begin{array}{c}4.97 \pm 2.86 \\
(27.1)\end{array}$ \\
\hline \multirow[t]{2}{*}{2} & 1 & n.d. & $\begin{array}{c}6.98 \pm 2.38 \\
(24.5)\end{array}$ & n.d. & $\begin{array}{c}7.17 \pm 1.99 \\
(18.0)\end{array}$ \\
\hline & 4 & $\begin{array}{l}9.48 \\
(27.4)\end{array}$ & $\begin{array}{c}6.44 \pm 1.57 \\
(23.2)\end{array}$ & $\begin{array}{c}7.74 \\
(29.8)\end{array}$ & $\begin{array}{c}4.88 \pm 1.98 \\
(20.4)\end{array}$ \\
\hline \multirow[t]{2}{*}{3} & 1 & n.d. & $\begin{array}{c}5.21 \pm 2.32 \\
(26.3)\end{array}$ & n.d. & $\begin{array}{c}4.64 \pm 3.21 \\
(31.0)\end{array}$ \\
\hline & 4 & $\begin{array}{l}22.64 \\
(60.0)\end{array}$ & $\begin{array}{l}16.38 \\
(46.8)\end{array}$ & $\begin{array}{l}30.40 \\
(70.8)\end{array}$ & $\begin{array}{c}15.34 \\
(50.72)\end{array}$ \\
\hline
\end{tabular}

$*$ Mean \pm standard deviation ( $n=3$; values without standard deviation $n=1$ ).

between the SML and the ULW were consistently $<9 \%$. During this experiment, there was a drastic change in community composition of the bacterioplankton between the first and the second day, most likely due to an inflow of brackish water into the limnic harbor (Supplement Fig. 1b). These changes were also observed in the SML inside and outside the mesocosms (Fig. 4b).
Taken together, all of the parameters in the SML inside and outside the mesocosms were highly dynamic and highly variable, with changes in their enrichment factors within each experiment (Fig. 3). Nevertheless, although the differences among all SML samples were not significant, the enrichment factors inside the mesocosms, especially for bacterial parameters, tended to be higher than the mean enrichment outside 
the mesocosms (Fig. 3). Additionally, the enrichment of particulate matter inside the mesocosms was always enhanced compared to values outside the mesocosms.

\section{Discussion}

\subsection{Organic matter in the sea-surface microlayer}

Organic matter in the SML is a complex mixture of substances, with major contributions of carbohydrates, proteins, and lipids (Williams et al., 1986; Kattner et al., 1985). It is well known that the dissolved fraction of organic matter is slightly, but consistently enriched in the SML (Hunter, 1997). Also, SML samples from the coastal zone of the southern Baltic Sea in this study showed only minor enrichments of DOC and DN. Enrichment factors ranged between 1.0 and 1.3 , comparable to previously reported values from different aquatic habitats (Momzikoff et al., 2004; Reinthaler et al., 2008; Wurl and Holmes, 2008). Moreover, absolute and relative concentrations of dissolved organic matter revealed only slight temporal variability throughout the sampling period. This was even observed during the formation and disintegration of a dense surface film (slick), which confirms the findings of a previous study, in which concentrations of dissolved organic matter were constant in a transition zone from a "clean" SML to a dense slick (Carlson, 1982).

Reinthaler et al. (2008) reported that only a minor portion $(\sim 6 \%)$ of the TOC pool in the SML of the Mediterranean Sea consisted of the particulate size fraction. However, in that study, most of the samples were taken when wind speeds were $>4 \mathrm{~m} \mathrm{~s}^{-1}$. High contributions of POC and PN to the total organic matter pool were determined in our field study during and after slick formation. Overall, in the SML, enrichment of the particulate fractions of organic carbon and nitrogen was consistently higher than that of the dissolved fractions. Enrichment factors for POC in the visible and in the disintegrating slick were 26.8 and 24.0, respectively, and were similar to the values reported for other coastal slicks, although 40-fold enrichments have also been cited (Carlson, 1983; Garabetian et al., 1993).

In the mesocosm experiments, similar proportions of the dissolved and particulate fraction were observed as in the field study. Enrichment factors of DOC and DN ranged between 1.0 and 1.7 and were not different in the artificially calmed mesocosms compared to the natural wind-influenced SML outside the mesocosms (data not shown). In contrast, enrichment factors for POC and PN ranged between 2.2 and 30.4 and were always higher inside than outside the mesocosms. Furthermore, POC (up to 60\%) and PN (up to 71\%) had major contributions to the total organic matter pool of each element. Again, contributions were much higher in the artificially calmed SML inside the mesocosms. Consequently, although distinction of the dissolved and particulate fractions was only possible in a subset of samples, the changing concentrations of particles in the SML were most likely the major driving force of temporal variability in the enrichment of TOC and TN. Furthermore, the variability in particulate matter enrichment could have caused the low or absent correlation of TOC and TN concentrations between the SML and the ULW in all mesocosm experiments.

While the origin of organic matter in the SML in the present study could not be elucidated, there were several indications of a contribution by the ULW: (1) Concentrations of DOC, DN, POC, and PN in the ULW on 6 May were slightly higher than in the following days $(\sim 15 \%$, data not shown). The high particulate load in the slick might therefore have arisen from the aggregation of dissolved and/or particulate matter in the ULW (Azetsu-Scott and Passow, 2004; Kerner et al., 2003), with subsequent transport to the SML by buoyant particles or rising bubbles (Wallace and Duce, 1978). (2) Phytoplankton activity can support the accumulation of material in the SML by the production of TEP or surfactants (Cunliffe et al., 2009b; Gašparovič et al., 2007; Wurl and Holmes, 2008). In the present study, slick formation developed during the productive spring season and, therefore, might have been fueled by autotrophic production. In addition, the lowest enrichment of particulate matter in the mesocosms was measured during the second experiment, which was characterized by constantly low concentrations of chlorophyll- $a$ in the ULW, implying a reduced influence of phytoplankton activity (Supplement Fig. 1b).

\subsection{Bacterial dynamics in the SML}

Absolute bacterial abundance in the SML from the coastal Baltic Sea was comparable to that in a recent study in this area (Stolle et al., 2009). Based on the strong increase in particulate organic matter in the slick, bacteria could have been passively transported to the SML by attachment to existing or newly formed particles in the ULW, which, in turn, might have caused the increase in the abundance of bacterial cells in the slick. Similarly, import from the bulk water was previously suggested to be the major source of enrichment of bacterial cells and virus-like particles in coastal and openocean SML samples (Kuznetsova et al., 2004). Comparable to slick formation, the abundance of total and CTC-positive cells as well as productivity in the SML changed during the first and third experiments inside the mesocosms, although the enrichment of CTC-positive cells was highly variable in all SML samples, as previously reported (Stolle et al., 2009).

Generally, the dynamics of the SML outside the mesocosms were similar to those inside the mesocosms throughout the three experiments. This was most likely due to the overall low influence of waves and wind in the sheltered harbor and resulted in similar enrichments inside and outside the mesocosms. Nevertheless, within each experiment, the highest enrichment factors were measured inside the mesocosms, 
especially for bacterial productivity and concentrations of organic matter.

Overall, for bacterial parameters, the highest enrichment factors followed the patterns of TOC and TN concentrations, suggesting that the accumulation of new material in the SML was coupled to the responses of the bacterioneuston. High concentrations of organic matter could explain previous reports of enhanced exo-enzymatic activities in the SML (Münster et al., 1997; Kuznetsova and Lee, 2001; Santos et al., 2009). However, low bacterial growth efficiencies in the SML of the Atlantic Ocean and the Mediterranean Sea imply that high bacterioneuston metabolism does not reflect enhanced cell growth (Reinthaler et al., 2008). These observations were suggested as indicators of stressful conditions in the SML (Dietz et al., 1976). Similar conclusions can be drawn from the present study, since despite the strong increase in absolute bacterioneuston productivity in the slick, cell-specific activity $\left({ }^{3} \mathrm{H}-\mathrm{TdR}\right.$ incorporation/cell) remained less than in the ULW (data not shown). This was also true for cell-specific activity in the SML of the mesocosm experiments, except on the third day of each experiment (data not shown). This exception might have been at least partially due to a smaller inhibitory influence of UV radiation in the mesocosm experiments due to the sampling season as well as the sampling time shortly after sunrise. The SML receives higher doses of UV radiation than the ULW (Maki, 1993). Generally, seasonally low radiation levels might also explain why ${ }^{3} \mathrm{H}-\mathrm{TdR}$ incorporation was not decreased to the same extent as in SML samples from the Baltic Sea, in this and in a previous study (Stolle et al., 2009). However, there is contradictory evidence regarding whether UV radiation generally causes diel patterns of bacterioneuston activity (Carlucci et al., 1986; Santos et al., 2009). Thereby, the matrix-like structure of the SML might on the one hand protect the bacterioneuston from UV-radiation comparable to biofilm habitats (Elasri and Miller, 1999) or on the other hand increase stress by photodegradation products such as $\mathrm{H}_{2} \mathrm{O}_{2}$ (Anesio et al., 2005). Nonetheless, cell-specific activity might have been even overestimated, as particle-attached bacteria were not counted due to methodological reasons. Particle-attached bacteria have been reported to be present in high numbers in the SML (Aller et al., 2005), which could explain the extensive enrichment of bacteria, up to several orders of magnitude, in slick samples (Hardy and Apts, 1984). Furthermore, relative bacterial productivity was found to be smallest when concentrations of particulate matter were highest (Obernosterer et al., 2008). This implies that particle attachment does not shelter bacteria from stress factors in the SML, although the general high activity of particle-attached bacteria in surface waters is known (Grossart et al., 2007). Bacterial attachment to particulate matter in the SML could also explain the decrease in bacterial abundance and productivity during slick disintegration. Increasing wind speed and a collapse of the SML due to increasing surface pressure and convergent forces (Wheeler, 1975) most likely caused a transport of material from the SML into the ULW, and might account for the strong increase in bacterioplankton productivity that occurred on 8 May.

Studies of bacterioneuston community composition are still scarce and to the best of our knowledge no attempt has yet been made to distinguish the non-attached and particleattached members of bacterioneuston communities. Several studies from coastal and estuarine habitats have shown distinct bacterioneuston and bacterioplankton communities (Fehon and Oliver, 1979; Franklin et al., 2008; Cunliffe et al., 2008). However, also strong variability in the bacterioneuston community from one day to the next has been reported (Agogué et al., 2005). Moreover, Cunliffe et al. $(2009 \mathrm{c})$ showed that the bacterioneuston community in a thick SML $(\sim 400 \mu \mathrm{m})$ differed increasingly from the bacterioplankton throughout the course of artificially induced phytoplankton blooms in closed mesocosms. Similarly, in this study, the community composition of non-attached bacteria in the coastal SML changed drastically upon slick formation and disintegration, whereas bacterioplankton community composition was stable over the sampling period. In contrast, differences in particle-attached community compositions were more pronounced and of longer duration. Again, the strongest effect was observed in the bacterioneuston upon slick formation. However, a dynamic pattern was also noted for the particle-attached community in the ULW between 6 May (pre-slick) and 7 May (slick). This implies that the movement and transformation of particles strongly impacts overall community structure. In the mesocosm experiments, the changing patterns of total bacterial community composition followed the dynamic enrichment of TOC and TN. Therefore, our results suggest that the observed dynamic variability in community composition was greatly influenced by the particle-attached community. Moreover, the bacterioneuston was found to be greatly influenced by the ULW, as the large changes in bacterioplankton community composition that occurred in the second experiment were immediately recognizable in the SML. In that experiment, general changes of the bacterioneuston inside the mesocosms were relatively small, and, interestingly, accompanied by the lowest concentrations of particulate organic matter in the SML, additionally indicating the importance of particles in the SML.

\subsection{Succession of the SML}

The SML is physically stable due to surface tension forces. While wave breaking disrupts the sea surface, re-assemblage of the SML occurs very rapidly (Hardy, 1982). Decreasing wind speed and an increasing accumulation of matter in the SML reduces surface tension, which finally dampens capillary waves and induces slick formation. Slicks are frequently observed in marine systems (Romano, 1996). Therefore, the SML is altered between these extremes, further complicating our attempts at elucidating the processes at the air-water 
Table 4. Correlations between the enrichment of bacterial parameters and total and particulate matter. Correlations with total organic carbon and total nitrogen are based on SML samples from the southern Baltic Sea taken in 2007 (Stolle et al., 2009) and in May 2008 as well as during the mesocosm experiments. Correlations with particulate organic carbon and particulate nitrogen are based on samples from May 2008 as well as on several mesocosm samples (see Table 3).

\begin{tabular}{|c|c|c|c|c|c|c|}
\hline & \multicolumn{3}{|c|}{ Total organic carbon } & \multicolumn{3}{|c|}{ Particulate organic carbon } \\
\hline & $r_{\mathrm{s}}$ & $p$ & $n$ & $r_{\mathrm{S}}$ & $p$ & $n$ \\
\hline Total bacterial cells & 0.522 & $<0.001$ & 57 & 0.794 & $<0.001$ & 23 \\
\hline CTC-positive cells & 0.555 & $<0.001$ & 58 & 0.583 & 0.003 & 24 \\
\hline \multirow[t]{3}{*}{${ }^{3} \mathrm{H}-\mathrm{TdR}$ incorporation } & 0.380 & 0.003 & 58 & 0.418 & 0.042 & 24 \\
\hline & \multicolumn{3}{|c|}{ Total nitrogen } & \multicolumn{3}{|c|}{ Particulate nitrogen } \\
\hline & $r_{\mathrm{s}}$ & $p$ & $n$ & $r_{\mathrm{S}}$ & $p$ & $n$ \\
\hline Total bacterial cells & 0.406 & 0.002 & 57 & 0.835 & $<0.001$ & 23 \\
\hline CTC-positive cells & 0.408 & 0.001 & 58 & 0.739 & $<0.001$ & 24 \\
\hline${ }^{3} \mathrm{H}-\mathrm{TdR}$ incorporation & 0.187 & n.s & 58 & 0.384 & n.s & 24 \\
\hline
\end{tabular}

$r_{\mathrm{S}}=$ Spearman rank correlation coefficient; $p=$ level of significance; $n=$ number of samples

interface. It is clear, however, that wind induces both removal and supply processes in the SML and contributes strongly to its temporal and spatial variability, even over very short time scales (Kuznetsova and Lee, 2002). Still, a simple relation between wind speed and changing concentrations of compounds in the SML cannot be concluded (Kuznetsova et al., 2004; Reinthaler et al., 2008).

Field studies and mesocosm experiments in the coastal zone of the Baltic Sea were employed in the present study to examine the effects of minimized wind-induced turbulence on the coastal SML. Generally, mesocosms provide valuable experimental setups to study biological responses to perturbations in aquatic systems (Riebesell et al., 2008). There are, however, potential drawbacks that complicate the extrapolation of the results obtained to unperturbed, natural systems (Riebesell et al., 2008). In the present study, the mesocosms might have e.g. artificially enhanced the enrichment of organic matter in the SML by preventing horizontal dilution or dispersion. However, the characteristics of the organic matter and its enrichment are comparable to the extensive slick formation in the same area (see above). Furthermore, as this study aimed to investigate the principal mechanisms of organic matter enrichment and the bacterioneuston response, we think that potential artefacts caused by the mesocosms can be neglected. Such an overestimation of organic matter concentrations, however, has to be considered when future studies might aim to balance fluxes of organic matter into, away or across the SML under varying low wind conditions.

Although the present study has some limitations due to the limited observation period, it can be speculated that very low wind speed induces a succession of physico-chemical features of the coastal Baltic Sea SML and its inhabiting bacterial community (Fig. 5). This succession is characterized by an uncoupling of bacterial parameters in the SML from those

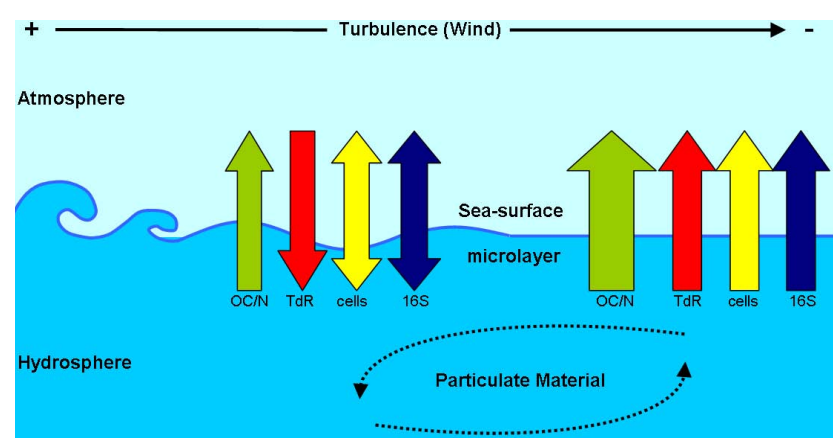

Fig. 5. Model of the effect of decreasing wind speed on organic matter enrichment and bacterioneuston parameters in the sea-surface microlayer compared to the underlying water. The present study indicates that slick formation and an artificial calming of the sea surface result in an increasing importance of the particulate fraction in the SML under lower wind conditions. (OC/N = organic carbon and nitrogen, $\mathrm{TdR}={ }^{3} \mathrm{H}$-thymidine incorporation, cells $=$ bacterial abundance, $16 \mathrm{~S}=$ differences in community composition based on 16S rRNA fingerprints).

in the ULW as well as an increased coupling of organic matter and bacteria in the SML under decreasing wind-induced surface mixing. Total bacterial abundance and productivity in the SML outside the mesocosms correlated very well with changing concentrations in the ULW. In contrast, this correlation was absent in the artificially calmed sea surfaces inside the mesocosms. There is contradictory evidence whether matter in the SML is related to that in the ULW (Dietz et al., 1976; Williams et al., 1986; Joux et al., 2006). Our study suggests that an uncoupling of the SML is favored under lowwind conditions. This is especially pronounced during slick formation, when bacterial parameters change strongly. 
Under these conditions, the contribution of the particulate fraction to the dynamic enrichment of organic matter and bacterial parameters in the SML increases. This is supported by strong correlations between the enrichment of POC and $\mathrm{PN}$ and the enrichment of bacterial abundances in the SML (Table 4). Considering all of the data from this study and a previous one (Stolle et al., 2009), patterns of TOC and TN enrichment do not as adequately explain the changes in bacterial abundances as do POC and PN enrichments. Patterns of bacterioneuston productivity were not or only weakly linked to changing quantities of organic matter in the SML, contrary to previously reported correlations between community respiration and TOC enrichment in the SML (Obernosterer et al., 2005). Nonetheless, the results of the present study underline earlier suggestions that the bacterioneuston community is not specifically adapted to this unusual habitat concerning the cycling of organic matter in the SML (Obernosterer et al., 2008).

\section{Conclusions}

Taken together, the high variability in the physical and chemical environment of the SML makes general characterizations of SML properties and assumptions about processes in this habitat a challenging task. The present study implies that further knowledge of particle transformation is essential to understand patterns of the coastal bacterioneuston community. Finally, meteorological conditions dominantly influence the status of the SML, and calm conditions have the potential to induce a succession of the bacterioneuston community, which, in turn, might be important for specific processes, e.g., gas exchange, especially during extensive surface phytoplankton blooms.

\section{Supplementary material related to this article is available online at: http://www.biogeosciences.net/7/2975/2010/ bg-7-2975-2010-supplement.zip.}

Acknowledgements. We are very grateful to W. Mohr for conceptual discussions and thank U. Hehl, M. Poetzsch, and A. Brietzke for excellent assistance during sampling in the southern Baltic Sea and during installation of the mesocosms. The technical assistance of C. Meeske and A. Gruettmueller during lab work is also highly appreciated. Furthermore, we thank I. Topp for chlorophyll-a and S. Weinreben for salinity measurements. This study was financed by the German Leibniz Society (WGL-PAKT project FILGAS) and the Federal Ministry of Education and Research (SOPRAN Phase II).

Edited by: T. J. Battin

\section{References}

Agogué, H., Casamayor, E. O., Joux, F., Obernosterer, I., Dupuy, C., Lantoine, F., Catala, P., Weinbauer, M. G., Reinthaler, T., Herndl, G. J., and Lebaron, P.: Comparison of samplers for the biological characterization of the sea surface microlayer, Limnol. Oceanogr.-Meth., 2, 213-225, 2004.

Agogué, H., Casamayor, E. O., Bourrain, M., Obernosterer, I., Joux, F., Herndl, G. J., and Lebaron, P.: A survey on bacteria inhabiting the sea surface microlayer of coastal ecosystems, FEMS Microbiol. Ecol., 54, 269-280, 2005.

Aller, J. Y., Kuznetsova, M. R., Jahns, C. J., and Kemp, P. F.: The sea surface microlayer as a source of viral and bacterial enrichment in marine aerosols, J. Aerosol Sci., 36, 801-812, 2005.

Anesio, A. M., Granéli, W., Aiken, G. R., Kieber, D. J., and Mopper, K.: Effect of Humic Substance Photodegradation on Bacterial Growth and Respiration in Lake Water, Appl. Environ. Microbiol., 71, 6267-6275, 2005.

Azetsu-Scott, K. and Passow, U.: Ascending marine particles: Significance of transparent exopolymer particles (TEP) in the upper ocean, Limnol. Oceanogr., 49, 741-748, 2004.

Baastrup-Spohr, L. and Staehr, P.: Surface microlayers on temperate lowland lakes, Hydrobiologia, 625, 43-59, 2009.

Bigg, E. K., Leck, C., and Tranvik, L.: Particulates of the surface microlayer of open water in the central Arctic Ocean in summer, Mar. Chem., 91, 131-141, 2004.

Carlson, D. J.: Phytoplankton in marine surface microlayers, Can. J. Microbiol., 28, 1226-1234, 1982.

Carlson, D. J.: Dissolved organic materials in surface microlayers: Temporal and spatial variability and relation to sea state, Limnol. Oceanogr., 28, 415-431, 1983.

Carlucci, A. F., Craven, D. B., Robertson, K. J., and Williams, P. M.: Surface-film microbial populations: diel amino acid metabolism, carbon utilization, and growth rates, Mar. Biol., 92, 289-297, 1986.

Chin-Leo, G. and Kirchman, D. L.: Estimating bacterial production in marine waters from the simultaneous incorporation of thymidine and leucine, Appl. Environ. Microbiol., 54, 1934-1939, 1988.

Cunliffe, M., Schafer, H., Harrison, E., Cleave, S., Upstill-Goddard, R., and Murrell, J. C.: Phylogenetic and functional gene analysis of the bacterial and archaeal communities associated with the surface microlayer of an estuary, ISME J., 2, 776-789, 2008.

Cunliffe, M., Harrison, E., Salter, M., Schäfer, H., Upstill-Goddard, R. C., and Murrell, J. C.: Comparison and validation of sampling strategies for the molecular microbial analysis of surface microlayers, Aquat. Microb. Ecol., 57, 69-77, 2009a.

Cunliffe, M., Salter, M., Mann, P. J., Whiteley, A. S., UpstillGoddard, R. C., and Murrell, J. C.: Dissolved organic carbon and bacterial populations in the gelatinous surface microlayer of a Norwegian fjord mesocosm, FEMS Microbiol. Lett., 299, 248254, 2009 b.

Cunliffe, M., Whiteley, A. S., Newbold, L., Oliver, A., Schafer, H., and Murrell, J. C.: Comparison of bacterioneuston and bacterioplankton dynamics during a phytoplankton bloom in a fjord mesocosm, Appl. Environ. Microbiol., 75, 7173-7181, 2009c.

Cunliffe, M. and Murrell, J. C.: The sea-surface microlayer is a gelatinous biofilm, ISME J., 3, 1001-1003, 2009. 
Dietz, A. S., Albright, L. J., and Tuominen, T.: Heterotrophic activities of bacterioneuston and bacterioplankton, Can. J. Microbiol., 22, 1699-1709, 1976.

Elasri, M. O. and Miller, R. V.: Study of the Response of a Biofilm Bacterial Community to UV Radiation, Appl. Environ. Microbiol., 65, 2025-2031, 1999.

Falkowska, L.: 12-hour cycle of matter transformation in the sea surface microlayer in the offshore waters of the Gdansk Basin (Baltic Sea) during spring, Oceanolgia, 43, 201-222, 2001.

Fehon, W. C. and Oliver, J. D.: Taxonomy and distribution of surface microlayer bacteria from two estuarine sites, Estuaries, 2, 194-197, 1979.

Franklin, M. P., McDonald, I. R., Bourne, D. G., Owens, N. J. P., Upstill-Goddard, R. C., and Murrell, J. C.: Bacterial diversity in the bacterioneuston (sea surface microlayer): the bacterioneuston through the looking glass, Environ. Microbiol. 7, 723736, 2005.

Garabetian, F., Romano, J. C., Paul, R., and Sigoillot, J. C.: Organic matter composition and pollutant enrichment of sea surface microlayer inside and outside slicks, Mar. Environ. Res., 35, 323339, 1993.

Gasol, J. M. and Arístegui, J.: Cytometric evidence reconciling the toxicity and usefulness of CTC as a marker of bacterial activity, Aquat. Microb. Ecol., 46, 71-83, 2007.

Gašparovič, B., Plavšič, M., Ćosovič, B., and Saliot, A.: Organic matter characterization in the sea surface microlayers in the subarctic Norwegian fjords region, Mar. Chem., 105, 1-14, 2007.

GESAMP: Biological effects of chemical and radiative change in the sea surface, in: The sea-surface microlayer and its role in global change, GESAMP Reports and Studies, 27-51, 1995.

Grossart, H.-P., Tang, K. W., Kiørboe, T., and Ploug, H.: Comparison of cell-specific activity between free-living and attached bacteria using isolates and natural assemblages, FEMS Microbiol. Lett., 266, 194-200, 2007.

Hardy, J. T.: The sea surface microlayer: biology, chemistry and anthropogenic enrichment, Prog. Oceanogr., 11, 307-328, 1982.

Hardy, J. T. and Apts, C. W.: The sea-surface microlayer: phytoneuston productivity and effects of atmospheric particulate matter, Mar. Biol., 82, 293-300, 1984.

Harvey, R. W. and Burzell, L. A.: A simple microlayer method for small samples, Limnol. Oceanogr., 17, 156-157, 1972.

Hunter, K. A.: Chemistry of the sea-surface microlayer, in: The sea-surface and global change, edited by: Liss, P. S. and Duce, R. A., Cambridge University Press, Cambridge, 287-320, 1997.

Huehnerfuss, H.: On the problem of sea surface film sampling: a comparison of 21 microlayer-, 2 multilayer-, and 4 selected subsurface-samplers, Part 1, Sonderdr. Meerestechnik, 12, 137142,1981

Joux, F., Agogué, H., Obernosterer, I., Dupuy, C., Reinthaler, T., Herndl, G. J., and Lebaron, P.: Microbial community structure in the sea surface microlayer at two contrasting coastal sites in the northwestern Mediterranean Sea, Aquat. Microb. Ecol., 42, 91-104, 2006.

Kattner, G., Nagel, K., Eberlein, K., and Hammer, K.-D.: Components of natural surface microlayers and subsurface water, Oceanol. Acta, 8, 175-183, 1985.

Kerner, M., Hohenberg, H., Ertl, S., Reckermann, M., and Spitzy, A.: Self-organization of dissolved organic matter to micelle-like microparticles in river water, Nature, 422, 150-154, 2003.
Kuznetsova, M. and Lee, C.: Enhanced extracellular enzymatic peptide hydrolysis in the sea-surface microlayer, Mar. Chem., 73, 319-332, 2001.

Kuznetsova, M. and Lee, C.: Dissolved free and combined amino acids in nearshore seawater, sea surface microlayers and foams: Influence of extracellular hydrolysis, Aquat. Sci., 64, 252-268, 2002.

Kuznetsova, M., Lee, C., Aller, J., and Frew, N.: Enrichment of amino acids in the sea surface microlayer at coastal and open ocean sites in the North Atlantic Ocean, Limnol. Oceanogr., 49, 1605-1619, 2004.

Labrenz, M., Jost, G., and Jürgens, K.: Distribution of abundant prokaryotic organisms in the water column of the central Baltic Sea with an oxic-anoxic interface, Aquat. Microb. Ecol., 46, 177-190, 2007.

Lane, D.: 16S/23S rRNA Sequencing, in: Nucleic acid techniques in bacterial systematics, edited by: Stackebrandt, E. and Goodfellow, M., John Wiley \& Sons, Chichester, 115-175, 1991.

Liss, P. S. and Duce, R. A.: The sea surface and global change, Cambridge University Press, Cambridge, 1997.

Maki, J. S.: The air-water interface as an extreme environment, in: Aquatic microbiology: an ecological approach, edited by: Ford, T. E., Blackwell Scientific Publication, Boston, Massachusetts, 409-439, 1993.

Momzikoff, A., Brinis, A., Dallot, S., Gondry, G., Saliot, A., and Lebaron, P.: Field study of the chemical characterization of the upper ocean surface using various samplers, Limnol. Oceanogr.Meth., 2, 374-386, 2004.

Münster, U., Heikkinen, E., and Knulst, J.: Nutrient composition, microbial biomass and activity at the air-water interface of small boreal forest lakes, Hydrobiologia, 363, 261-270, 1997.

Nausch, G., Feistel, R., Umlauf, L., Nagel, K., and Siegel, H.: Hydrographisch-chemische Zustandseinschätzung der Ostsee, Meereswissenschaft. Ber., 77, 3-99, 2009.

Obernosterer, I., Catala, P., Reinthaler, T., Herndl, G. J., and Lebaron, P.: Enhanced heterotrophic activity in the surface microlayer of the Mediterranean Sea, Aquat. Microb. Ecol., 39, 293-302, 2005.

Obernosterer, I., Catala, P., Lami, R., Caparros, J., Ras, J., Bricaud, A., Dupuy, C., van Wambeke, F., and Lebaron, P.: Biochemical characteristics and bacterial community structure of the sea surface microlayer in the South Pacific Ocean, Biogeosciences, 5, 693-705, doi:10.5194/bg-5-693-2008, 2008.

Ploug, H.: Cyanobacterial surface blooms formed by Aphanizomenon sp. and Nodularia spumigena in the Baltic Sea: Small-scale fluxes, $\mathrm{pH}$, and oxygen microenvironments, Limnol. Oceanogr., 53, 914-921, 2008.

Reinthaler, T., Sintes, E., and Herndl, G. J.: Dissolved organic matter and bacterial production and respiration in the sea-surface microlayer of the open Atlantic and the western Mediterranean Sea, Limnol. Oceanogr., 53, 122-136, 2008.

Riebesell, U., Bellerby, R. G. J., Grossart, H.-P., and Thingstad, F.: Mesocosm $\mathrm{CO}_{2}$ perturbation studies: from organism to community level, Biogeosciences, 5, 1157-1164, doi:10.5194/bg-51157-2008, 2008.

Romano, J.-C.: Sea-surface slick occurrence in the open sea (Mediterranean, Red Sea, Indian Ocean) in relation to wind speed, Deep-Sea Res. Pt. I, 43, 411-423, 1996. 
Santos, A. L., Mendes, C., Gomes, N. C. M., Henriques, I., Correia, A., Almeida, A., and Cunha, A.: Short-term variability of abundance, diversity and activity of estuarine bacterioneuston and bacterioplankton, J. Plankton Res., 31, 1545-1555, 2009.

Schwieger, F. and Tebbe, C. C.: A new approach to utilize PCRsingle-strand-conformation polymorphism for 16S rRNA genebased microbial community analysis, Appl. Environ. Microbiol., 64, 4870-4876, 1998.

Sieburth, J. M. and Conover, J. T.: Slicks associated with Trichodesmium blooms in the Sargasso Sea, Nature, 205, 830-831, 1965.

Sieburth, J. M. N., Willis, P. J., Johnson, K. M., Burney, C. M., Lavoie, D. M., Hinga, K. R., Caron, D. A., French, F. W., Johnson, P. W., and Davis, P. G.: Dissolved organic matter and heterotrophic microneuston in surface microlayers of the North Atlantic, Science, 194, 1415-1418, 1976.

Södergren, A.: Origin and composition of surface slicks in lakes of differing trophic status, Limnol. Oceanogr., 32, 1307-1316, 1987.

Stolle, C., Nagel, K., Labrenz, M., and Jürgens, K.: Bacterial activity in the sea-surface microlayer: in situ investigations in the Baltic Sea and the influence of sampling devices, Aquat. Microb. Ecol., 58, 67-78, 2009.
Wallace, G. T. and Duce, R. A.: Transport of particulate organic matter by bubbles in marine waters, Limnol. Oceanogr., 23, 1155-1167, 1978.

Weinbauer, M. G., Fritz, I., Wenderoth, D. F., and Höfle, M. G.: Simultaneous extraction from bacterioplankton of total RNA and DNA suitable for quantitative structure and function analyses, Appl. Environ. Microbiol., 68, 1082-1087, 2002.

Wheeler, J. R.: Formation and collapse of surface films, Limnol. Oceanogr., 20, 338-342, 1975.

Williams, P. M., Carlucci, A. F., Henrichs, S. M., van Vleet, E. S., Horrigan, S. G., Reid, F. M. H., and Robertson, K. J.: Chemical and microbiological studies of sea-surface films in the southern Gulf of California and off the west coast of Baja California, Mar. Chem., 19, 17-98, 1986.

Wurl, O. and Holmes, M.: The gelatinous nature of the sea-surface microlayer, Mar. Chem., 110, 89-97, 2008.

Zhang, Z., Cai, W., Liu, L., Liu, C., and Chen, F.: Direct determination of thickness of sea surface microlayer using a $\mathrm{pH}$ microelectrode at original location, Sci. China Ser. B, 46, 339-351, 2003. 